\title{
First chromosome data on Steindachneridion doceanum (Siluriformes: Pimelodidae): a critically endangered catfish endemic of the Doce River basin, Brazil
}

\author{
Ana Claudia Swarça ${ }^{1}$, Mário Luis Orsi ${ }^{1}$, Fábio Hiroshi Takagui ${ }^{1}$, Ana Lucia Dias ${ }^{1}$, \\ Jorge Abdala Dergam ${ }^{2}$ and Alberto Sérgio Fenocchio ${ }^{3}$
}

The present report represents the first cytogenetic description of Steindachneridion doceanum, great catfish which is currently at high extinction risk and it is listed as threatened on the red list of the Brazilian Ministry of the Environment, also are suggested karyotype relationships with other species of the same genus endemic from other river basins. The results revealed a diploid number of $2 \mathrm{n}=56$ and the karyotype composed of 18 metacentric, 20 submetacentric, 10 subtelocentric and 8 acrocentric chromosomes $(\mathrm{NF}=104)$. The AgNORs and $\mathrm{CMA}_{3}$ signals were coincident in location occupying the short arm of an acrocentric chromosome pair (25th), in a secondary constriction. The 5S rDNA genes were localized on the short arms of one subtelocentric pair. C-banding revealed terminal blocks on the short arms on many chromosomes as well as terminal positive bands at the both ends of a submetacentric pair. $\mathrm{C}$ banding also revealed a large heterochromatic block in the secondary constriction $\left(25^{\text {th }}\right)$ region that was coincident with the AgNORs sites and CMA3 ${ }^{+}$bright bands. In spite $S$. doceanum represent an endemic taxon, in spite their geographic isolation their cytogenetic characteristics show similarities with other species of the genus.

Keywords: AgNORS, C band, Karyotype, South American Catfish, Threatened species.

O presente trabalho apresenta a primeira descrição citogenética de Steindachneridion doceanum, grande bagre que se encontra atualmente em alto risco de extinção e listado como ameaçado na lista vermelha do Ministério do Meio Ambiente, também sugere relações cariotípicas com outras espécies do mesmo gênero, endêmicas de outras bacias hidrográficas. Os resultados revelaram um número diplóide de 56 cromossomos e o cariótipo composto por 18 elementos metacêntricos, 20 submetacêntricos, 10 subtelocêntricos e 8 acrocêntricos $(\mathrm{NF}=104)$. As marcações AgNORs e CMA foram coincidentes ocupando o braço curto de um par de cromossomos acrocêntricos (par 25), em uma constrição secundária. Os genes 5S rDNA foram detectados nos braços curtos de um par subtelocêntrico. A banda $\mathrm{C}$ revelou blocos terminais nos braços curtos em vários cromossomos, bem como blocos terminais nas duas extremidades de um par submetacêntrico. A banda C também evidenciou um grande bloco heterocromático na constrição secundária (par 25) coincidente com os sítios AgNORs e as bandas CMA3 positivas. Apesar de $S$. doceanum representar um táxon endêmico, suas características citogenéticas mostram semelhanças com outras espécies do gênero das quais se encontra geograficamente isolado.

Palavras-chave: AgNORs, Bagre Sulamericano, Banda C, Cariótipo, Espécie Ameaçada

\section{Introduction}

The genus Steindachneridion Eigenmann \& Eigenmann, 1919 , commonly known as "surubim" or "monjolo", belongs to the Order Siluriformes, family Pimelodidae and has a restricted distribution in certain South America river basins
(Lundberg and Littmann, 2003). There are six valid species within the genus (Eschmeyer, Fong, 2017) and a common characteristic is the endemism of almost all of them: Steindachneridion amblyurum (Eigenmann \& Eigenmann, 1888) from the Jequitinhonha River basin, Steindachneridion doceanum (Eigenmann \& Eigenmann, 1889) from the Doce

\footnotetext{
${ }^{1}$ Universidade Estadual de Londrina, Centro de Ciências Biológicas. Rodovia Celso Garcia Cid, Km 380, Campus Universitário, 86.057-970 Londrina, PR, Brazil. (ACS) swarca@uel.br, (http://orcid.org/0000-0003-1492-2690 (corresponding author), (MLO) orsimario68@gmail. com, (FHT) fabiotakagui@hotmail.com, (ALD) anadias@uel.br

${ }^{2}$ Universidade Federal de Viçosa, Laboratório de Sistemática Molecular Beagle, 36570-000 Viçosa, MG, Brazil. dergam@ufv.br ${ }^{3}$ Universidad Nacional de Misiones, Departamento de Genetica, Instituto de Biologia Subtropical. Féliz de Azara 1552, 3300 Posadas, Mis., Argentina.afenocch@fceqyn.unam.edu.ar
} 
River basin, Steindachneridion parahybae (Steindachner, 1877) from the Paraíba River basin, Steindachneridion melanodermatum Garavelo, 2005 from Iguaçu River, upper Paraná River basin, Brazil and Argentina, Steindachneridion scriptum (Miranda Ribeiro, 1918) and Steindachneridion punctatum (Miranda Ribeiro, 1918) from Upper Paraná River and Uruguay River basin. There are two fossil species of Steindachneridion, Steindachneridion iheringi (Woodward, 1899) and Steindachneridion silvasantosi Figueiredo \& Costa-Carvalho, 1999 (Garavello, 2005; Ferraris, 2007).

Natural populations of Steindachneridion are scarce and rarely captured because of damming of rivers, overfishing, and contamination of freshwater environments. Some of them are highly endangered and with few biological (reproductive, ethological, physiological) studies being available. Consequently, the samples of Steindachneridion specimens are numerically very small and practically unavailable in ichthyologic collections (Garavello, 2005).

Steindachneridion doceanum is one of the greatest native fish from Doce River basin and according Rosa, Lima (2008) are included in Red List of the Brazilian Ministry of the Environment.

It is a species that has as specific habitats the deepest sites in the channel of the Doce River and its major tributaries, primarily in regions with rocky bottoms and located below rapids and waterfalls. The exclusive use of this type of environment was also described for the other species of the genus (Garavello, 2005).

The Doce River basin comprises a drainage area of about $83,715 \mathrm{~km}^{2}$, of which $86 \%$ belong to the state of Minas Gerais and remainder of the state of Espírito Santo (CBH-Doce, 2016). In November $5^{\text {th }}, 2015$, with the rupture of the Fundão Dam in Minas Gerais state, Brazil, 50 million $\mathrm{m}^{3}$ of rejects from the processing of iron ore were discharged in the Doce River main channel and their tributaries, destroying fish habitat and the aquatic ecosystem (IBAMA, 2015). This event was considered as the biggest environmental disaster in the history of Brazil and the worst accident with tailings dams ever recorded in the world.

Three species of the genus were previously studied cytogenetically, Steindachneridion scriptum (Swarça et al., 2005a), S. melanodermatum (= Steindachneridion sp.) (Swarça et al., 2006) and S. parahybae (Moraes-Neto et al., 2011). The aim of the present study was to characterize $S$. doceanum at the karyotypic level by means of standard and fluorescent in situ hybridization techniques comparing the obtained data with these from other Steindachneridion species.

\section{Material and Methods}

One male specimen of Steindachneridion doceanum was cytogenetically analyzed and collected by authorization of ICMBio (Instituto Chico Mendes de Conservação da Biodiversidade) and protocols have undergone an ethical review process by a local ethics committee. This specimen was collected at $20^{\circ} 30^{\prime} 56.47^{\prime} \mathrm{S}, 43^{\circ} 01^{\prime} 10.55^{\prime \prime} \mathrm{W}$, in the Piranga Ri-
ver/Minas Gerais/Brazil, close to the area impacted by the waste discharge (Fig.1). The specimen was anesthetized in Benzocaine (CAS Number 97-09-7 and DCB Number 01159) and sacrificed. Mitotic chromosomes were obtained by direct method following Bertollo et al. (1978) on the voucher specimen CT 1589, deposited in the ichthyological collection of the Universidade Federal de Viçosa. Chromosome morphology was determined based on Levan et al. (1964) and Guerra (1986) with some modifications (use "acrocentric" as "telocentric") and chromosomes were classified as metacentric (m), submetacentric (sm), subtelocentric (st) and acrocentric (a). FN (chromosome arm number) was determined considering $\mathrm{m} / \mathrm{sm} / \mathrm{st}$ chromosomes having two arms and acrocentric chromosomes having one single arm. Assays conducted to reveal the pattern of constitutive heterochromatin (C banding) were carried out according to Sumner (1972) with a modification in the staining phase by replacing Giemsa with $20 \mu \mathrm{L}$ of an antifade solution and $0.7 \mu \mathrm{L}$ propidium iodide, as suggested by Lui et al. (2012). Nucleolus organizer regions (Ag-NORs) were visualized with silver staining following Howell, Black (1980) and Chromomycin A3 (CMA3) staining were carried out using the method of Schweizer (1976). Fluorescence in situ hybridization (FISH) was carried out according to Pinkel et al. (1986) using 5S rDNA probe (Martins, Galetti, 1999) labelled with biotin-16-dUTP by nick translation (Biotin Nick Translation mix, Roche), according the manufacturer's instructions. The preparations were analyzed in an Olympus BX50 microscope, and the best metaphases were captured with a SONY camera, model Exware HAD coupled to the microscope. FISH slides images were acquired with a Leica DM 4500 microscope equipped with a DFC 300F9 camera and Leica IM50 4.0 software.

\section{Results}

The diploid number determined for Steindachneridion doceanum was 56 chromosomes and the karyotype composed of 18 metacentric, 20 submetacentric, 10 subtelocentric and 8 acrocentric chromosomes $(\mathrm{NF}=104)$ (Fig. 2a). A consistently observed characteristic was the presence of a secondary constriction on the short arm of pair 25. C-banding revealed terminal blocks on the short arms on many chromosomes $(3,6,15,20,21$ and 22 pairs) as well as terminal blocks at the both ends of a submetacentric pair (16th) (Fig. $2 \mathrm{~b})$. $\mathrm{C}$ banding also revealed a large heterochromatic block in the secondary constriction $\left(25^{\text {th }}\right)$ region and is coincident with the AgNORs sites and $\mathrm{CMA}^{+}$bright bands (Figs. 2cd). The FISH with $5 \mathrm{~S}$ rDNA probe revealed fluorescent signals on the short arm of a single subtelocentric pair (Fig. 2e).

\section{Discussion}

The present report represents the first karyotypic description of Steindachneridion doceanum fish species that are included in Red List of the Brazilian Ministry of the Environment. After many attempts, it was possible to collect 


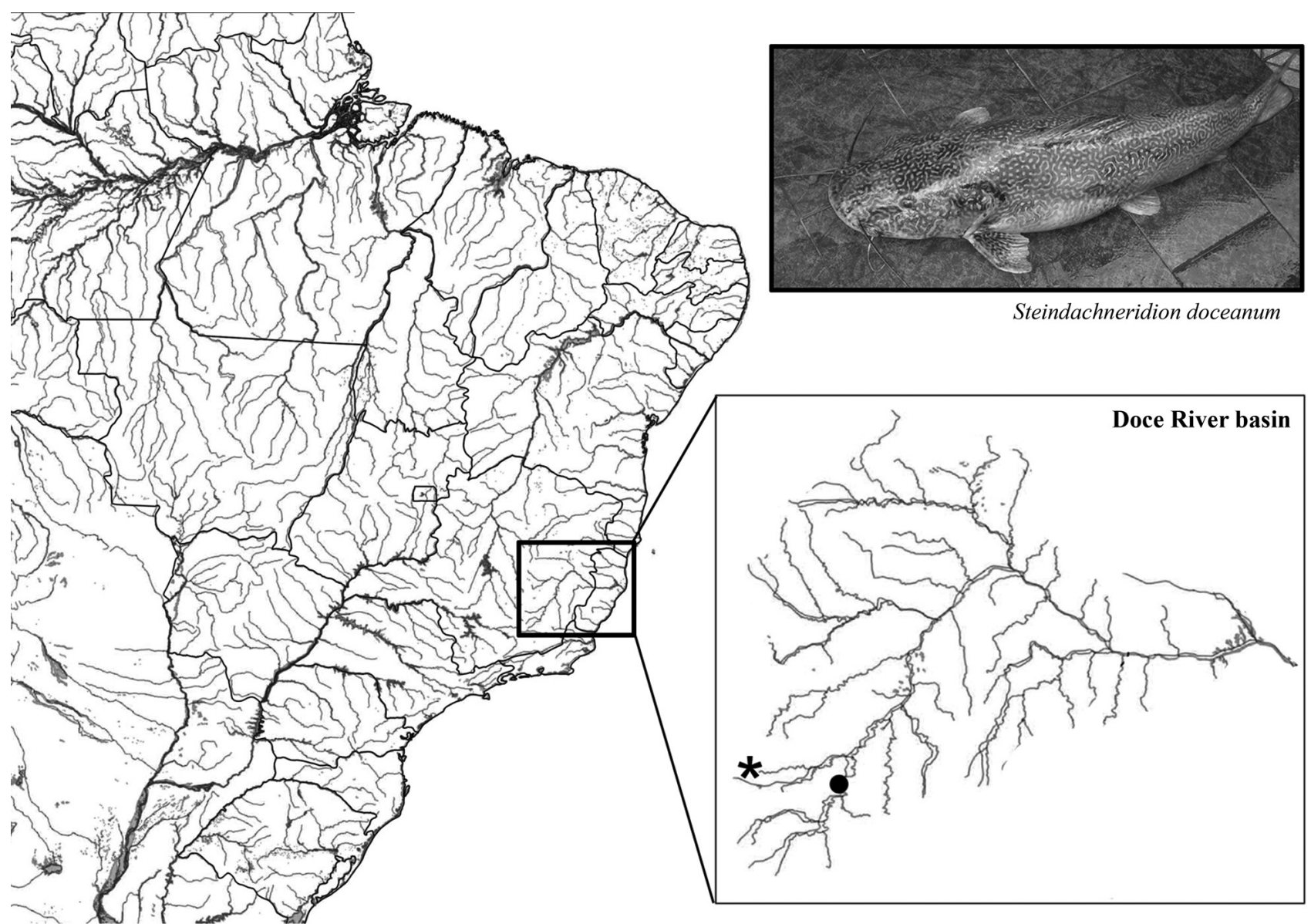

Fig. 1. Specimen of Steindachneridion doceanum. Partial map of Brazil showing the localization of the Doce River basin. The dot represents the collection location (Piranga River) and the asterisk the impacted by the waste discharge.

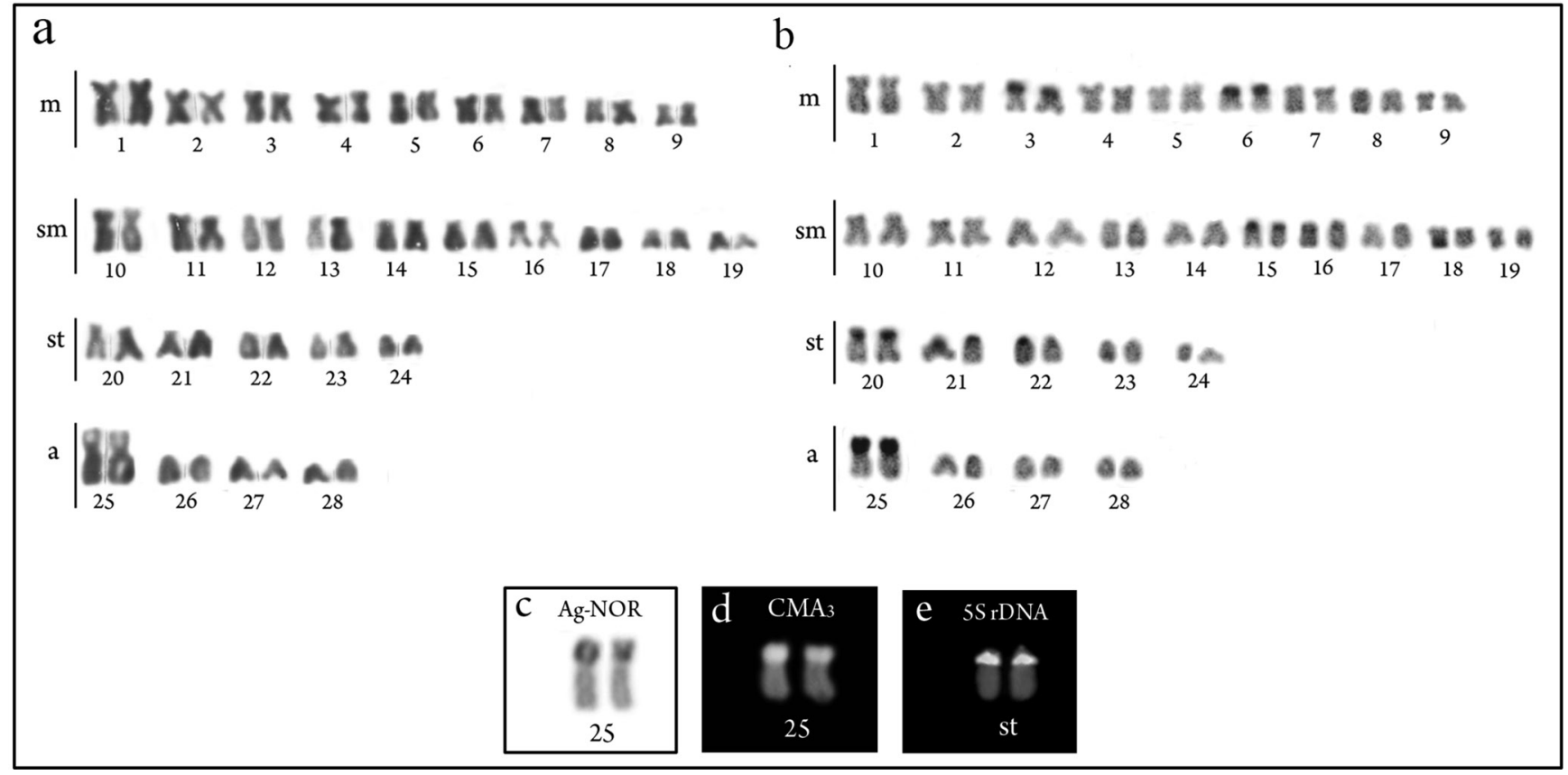

Fig. 2. Karyotypes of $S$. doceanum: a. Giemsa staining; b. C-banding pattern characterized by the many heterochromatin blocks in different positions. In the boxes chromosome pairs of $S$. doceanum: c. Ag-NOR sites; d. CMA3 staining; e. FISH with 5S DNAr probe. 
Tab. 1. Karyotype characteristics of the studied species of the genus Steindachneridion. $2 \mathrm{n}=$ diploid number; $\mathrm{FN}=$ fundamental number; $\mathrm{m}=$ metacentrics; $\mathrm{sm}=$ submetacentrics; $\mathrm{st}=$ subtelocentrics; $\mathrm{a}=$ acrocentrics, $\mathrm{PR}=$ Paraná state, $\mathrm{RJ}=$ Rio de Janeiro State, $\mathrm{MG}=$ Minas Gerais State; $p=$ short arm.

\begin{tabular}{|c|c|c|c|c|c|c|c|c|}
\hline Genera/Species & Locality/State & $2 n$ & Karyotype & FN & AgNORs & 5SrDNA & C-Band & References \\
\hline S. scriptum & $\begin{array}{l}\text { Paranapanema } \\
\text { River, PR }\end{array}$ & 56 & $24 m+20 s m+4 s t+8 a$ & 104 & $\begin{array}{l}p \text { terminal a } \\
\text { chromosome }\end{array}$ & $\begin{array}{l}p \text { subterminal st } \\
\text { chromosome }\end{array}$ & $\begin{array}{l}\text { Terminal and } \\
\text { bitelomeric }\end{array}$ & $\begin{array}{l}\text { Swarça et al. } \\
(2005)\end{array}$ \\
\hline S. melanodermatum & Iguaçu River, PR & 56 & $\begin{array}{l}20 \mathrm{~m}+24 \mathrm{sm}+2 \mathrm{st}+10 \mathrm{a} \\
21 \mathrm{~m}+23 \mathrm{sm}+2 \mathrm{st}+10 \mathrm{a}\end{array}$ & 102 & $\begin{array}{l}p \text { terminal a } \\
\text { chromosome }\end{array}$ & $\begin{array}{l}p \text { subterminal st } \\
\text { chromosome }\end{array}$ & Weak -C-bands & $\begin{array}{l}\text { Swarça et al. } \\
(2006)\end{array}$ \\
\hline S. parahybae & $\begin{array}{l}\text { Paraíba do Sul } \\
\text { River, RJ }\end{array}$ & 56 & $14 \mathrm{~m}+22 \mathrm{sm}+12 \mathrm{st}+8 \mathrm{a}$ & 104 & $\begin{array}{l}p \text { terminal sm } \\
\text { chromosome }\end{array}$ & $\begin{array}{l}p \text { interstitial sm } \\
\text { chromosome }\end{array}$ & $\begin{array}{l}\text { Centromeric, } \\
\text { terminal and } \\
\text { bitelomeric }\end{array}$ & $\begin{array}{l}\text { Honji et al. } \\
\text { (2016); Moraes } \\
\text { Neto et al. (2011) }\end{array}$ \\
\hline S. doceanum & $\begin{array}{l}\text { Piranga River, } \\
\text { MG }\end{array}$ & 56 & $18 m+20 s m+10 s t+8 a$ & 104 & $\begin{array}{l}p \text { terminal a } \\
\text { chromosome }\end{array}$ & $\begin{array}{l}p \text { subterminal st } \\
\text { chromosome }\end{array}$ & $\begin{array}{l}\text { Terminal and } \\
\text { bitelomeric }\end{array}$ & Present paper \\
\hline
\end{tabular}

only one specimen, probably due to the dramatic modification suffered by great part of their endemic distribution area even before the dramatic ecological disaster suffered as consequence of the dam break of Mariana city, state of Minas Gerais, Brazil.

Cytogenetic studies on Steindachneridion are available for S. scriptum (Swarça et al., 2005a), S. melanodermatum (= Steindachneridion sp.) (Swarça et al., 2006) and S. parahybae (Moraes-Neto et al., 2011) and despite sharing some chromosomal similarities, cytogenetic traits of the $S$. doceanum (present paper) such as karyotypic formula, AgNORS and C-banding patterns were divergent (Tab. 1). $S$. scriptum, $S$. melanodermatum and $S$. doceanum share a very decondensed secondary constriction in the first acrocentric pair and number and location of AgNORs and 5S rDNA sites (Swarça et al., 2006; 2007; present paper). The differences appeared in $S$. parahybae that shows the silver impregnation on the short arm of a submetacentric chromosome pair in terminal position (Moraes-Neto et al., 2011). These small or subtle differences should be carefully analyzed to be considered as specific marker cytogenetic traits.

On the other hand, sometimes is hard to establish comparisons because appeared some apparent mistakes in published data, as is the case of S. parahybae that show discordances in the number of chromosome types among text and tables (Moraes-Neto et al., 2011; Honji et al., 2016).

Differentiation among Steindachneridion species are probably due to non-Robertsonian chromosome rearrangements (chromosomal inversions) associated to the historical biogeography characterized by a strong vicariant process that leads to the typical allopatric geographical distribution with high levels of endemism.

Heterochromatin was evidenced on terminal chromosome regions of some pairs, another pair shows "bitelomeric" bands and was also observed in the secondary constrictions on the short arm of NOR bearing pair. This last feature represents a common shared trait however the distribution of heterochromatic regions is slightly variable when compared the species of Steindachneridion (Tab. 1).

5S rDNA sites are not being associated with $18 \mathrm{~S}$ ribosomal genes. These results agree with other reports in Stein- dachneridion (Tab. 1), where the 5S rRNA sites are located interstitially and/or subterminally in different genome locations. This fact suggests that such chromosome distribution, being the most frequent, could provide certain advantages, i.e avoiding the lack or modification due to structural rearrangements (Martins, Galetti, 1999). On the other hand, the number, position and structure of the 5S rDNA genes on the karyotype seem to be conserved in the Steindachneridion species, trait that could represent cytogenetic markers in further cytotaxonomic and evolutionary studies.

All the mentioned characteristics were frequently reported in species of family Pimelodidae, especially in relation to the "Sorubiminae group", which includes-Steindachneridion (Fenocchio, Bertollo, 1992; Swarça et al., 2001, 2005b, 2007, 2013). Although Steindachneridion show along all they distribution endemic and geographically isolated species, the shared cytogenetic characteristics support the close relationships among this group to date.

\section{References}

Bertollo LAC, Takahashi CS, Moreira-Filho O. Cytotaxonomic considerations on Hoplias lacerdae (Pisces, Erythrinidae). Braz J Genet. 1978; 1:103-20.

Comitê da Bacia Hidrográfica do Rio Doce (CBH-Doce). A Bacia; 2014 [cited 2016 Nov 11]. Available from: http://www. cbhdoce.org.br/a-bacia/

Eschmeyer WN, Fong JD. Species by Family/Subfamily in the Catalogue of Fishes. 2017. [cited 2017 august 16]. Available from: http://researcharchive.calacademy.org/research/ichthyology/ catalog/SpeciesByFamily.asp

Fenocchio AS, Bertollo LAC. Karyotype similarities among Pimelodidae (Pisces, Siluriformes) from the Brazilian Amazon region. Cytobios.1992; 69(276):41-46.

Ferraris CJ. Checklist of catfishes, recent and fossil (Osteichthyes: Siluriformes), and catalogue of siluriform primary types. Zootaxa. 2007; 1418(1):1-628.

Garavello JC. Revision of genus Steindachneridion (Siluriformes: Pimelodidae). Neotrop ichthyol. 2005; 3(4):607-23.

Guerra M. Reviewing the chromosome nomenclature of Levan et al. Braz J Genet. 1986; 4:741-46.

Honji RM, Caneppele D, Pandolfi M, Nostro FLL, Moreira RG. A case of intersex occurrence in Steindachneridion parahybae 
(Steindachner, 1877) (Siluriformes: Pimelodidae) under captivity condition: a cytogenetic and morphological study. Neotrop ichthyol. 2016; 14(4): e160077. Available from: http:// dx.doi.org/10.1590/1982-0224-20160077

Howell WM, Black DA. Controlled silver-staining of nucleolus organizer regions with a protective colloidal developer: a 1-step method. Experientia. 1980; 36(8):1014-15.

Instituto Brasileiro do Meio Ambiente (IBAMA). Laudo Técnico Preliminar: Impactos ambientais decorrentes do desastre envolvendo o rompimento da barragem de Fundão, em Mariana, Minas Gerais; 2015.

Levan A, Fredga K, Sandberg AA. Nomenclature for centromeric position on chromosomes. Hereditas. 1964; 52(2):201-20.

Lui RL, Blanco DR, Moreira-Filho O, Margarido VP. Propidium iodide for making heterochromatin more evident in the C-banding technique. Biotech Histochem. 2012; 87(7):433-38.

Lundberg JG, Littmann MW. Family Pimelodidae. In: Reis RE, Kullander SO, Ferraris CJ, Jr., organizers. Check list of the freshwater fishes of South and Central America. Porto Alegre: Edipucrs; 2003. p.432-442.

Martins C, Galetti PM, Jr. Chromosomal localization of 5S rDNA genes in Leporinus fish (Anostomidae, Characiformes). Chromosome Res. 1999; 7(5):363-67.

Moraes-Neto A, Silva M, Matoso DA, Vicari MR, Almeida MC, Collares-Pereira MJ, Artoni RF. Karyotype variability in neotropical catfishes of the family Pimelodidae (Teleostei: Siluriformes). Neotrop ichthyol. 2011; 9(1):97-105.

Pinkel D, Straume T, Gray JW. Cytogenetic analysis using quantitative, high-sensitivity, fluorescence hybridization. Proc Natl Acad Sci USA. 1986; 83(9):2934-38.

Rosa RS, Lima FCT. Peixes. In: Machado ABM, Drummond GM, Paglia AP, editores. Livro Vermelho da Fauna Brasileira Ameaçada de Extinção. Volume II. Brasília: Ministério do Meio Ambiente; 2008. p.8-285.

Schweizer D. Reverse fluorescent chromosome banding with chromomycin and DAPI. Chromosoma. 1976; 58(4):307-24.
Sumner AT. A simple technique for demonstrating centromeric heterochromatin. Exp Cell Res. 1972; 75(1):304-306.

Swarça AC, Cestari MM, L. Giuliano-Caetano L, Dias AL. Cytogenetic characterization of the large south American Siluriform fish species Zungaro (Pisces, Pimelodidae). Chromosome Sci. 2001; 5:51-55.

Swarça AC, Fenocchio AS, Cestari MM, Dias AL. First chromosome data on Steindachneridion scripta (Pisces, Siluriformes, Pimelodidae) from Brazilian rivers: Giemsa, CBG, G-, and RE banding. Genet Mol Res. 2005a; 4(4):734-741.

Swarça AC, Fenocchio AS, Cestari MM, Dias AL. Karyotype divergence among populations of giant catfish Pseudoplatystoma corruscans (Teleostei: Pimelodidae) indicates higher species diversity. Ichthological Exploration Freshwaters. 2005b; 16(4):325-30.

Swarça AC, Fenocchio AS, Cestari MM, Dias AL. First report of a sex chromosome system in a Sorubiminae fish, Steindachneridion sp. (Pimelodidae), with an uncommon large Y chromosome. Mitotic and meiotic analysis. Cytog Genome Research. 2006; 112:325-328.

Swarça AC, Fenocchio AS, Dias AL. An update cytogenetic review for species of the families Pseudopimelodidae, Pimelodidae and Heptapteridae (Pisces, Siluriformes). Suggestion of a cytotaxonomical classification. Caryologia. 2007; 60(4):33848.

Swarça AC, Sanchez S, Dias AL, Fenocchio AS. Cytogenetics of the Porthole Shovelnose Catfish, Hemisorubim platyrhynchos (Valenciennes, 1840) (Siluriformes, Pimelodidae), a widespread species in South American rivers. Comp Cytogenet. 2013; 7(2):103-10. 